\title{
腹腔鏡下手術において縫合針を破損、紛失した症例
}

国立病院機構 小倉医療センター 産婦人科 ${ }^{11}$ 、柳川病院 ${ }^{21}$

大藏尚文 ${ }^{1)}$ 、黑川裕 ${ }^{1)}$ 、西村和朗 ${ }^{1)}$ 、白水信之 ${ }^{1)}$ 、松本恵美 ${ }^{1)}$ 、川上浩介 ${ }^{1)}$ 、 藤吉直樹 ${ }^{1)}$ 、洲脇尚子 ${ }^{1)}$ 、熊谷晴 介 $^{1)}$ 、ウロブレスキ順子 ${ }^{1)}$ 、牟田 満 $^{1)}$ 、本村 聡 $^{2)}$

\section{Management of a Broken or Lost Needle during Laparoscopic Surgery}

\author{
Naofumi Okura $^{1)}$, Yusuke Kurokawa ${ }^{1)}$, Kazuaki Nishimura ${ }^{1)}$, Nobuyuki Shiramizu ${ }^{1)}$,
}

Emi Matsumoto ${ }^{1)}$, Kousuke Kawakami ${ }^{1}$, Naoki Fujiyoshi ${ }^{1}$, Naoko Suwaki ${ }^{1}$,

Seisuke Kumagai ${ }^{1)}$, Junko Wroblewski ${ }^{1)}$, Mitsuru Muta ${ }^{1)}$, Satoshi Motomura ${ }^{2}$

Department of Obstetrics and Gynecology,National Hospital Organization Kokura Medical Center ${ }^{1)}$,

Department of Obstetrics and Gynecology,Yanagawa Hospital ${ }^{2)}$

\begin{abstract}
Laparoscopic techniques have evolved from predominantly diagnostic to extensive operative procedures. Surgical techniques traditionally performed in an open fashion are being conducted laparoscopically with increasing frequency. With these developments, the indications for laparoscopic suturing have increased accordingly. Caution is required to avoid breaking or losing a needle during extracorporeal suturing. We describe the breakage and subsequent recovery of $1.5 \mathrm{~mm}$ segments of surgical needles during a laparoscopic myomectomy and a total laparoscopic hysterectomy. Most current research has focused on preventative and detection strategies for lost needles; however, there are no known methods of completely preventing occurrences of these unforeseen events. In this paper, we discuss a literature review of needles lost during laparoscopic surgery.
\end{abstract}

Key words: laparoscopic surgery, broken needle, lost needle

\section{緒 言}

手術での縫合針の破損および紛失は稀に遭遇す る術中合併症である。全ての診療科に扔ける全手 術の $0.07 \%$ に器具の破損があり ${ }^{1)}$ 、婦人科腹腔鏡 下手術の $0.09 \%$ に縫合針の紛失が認められている2)。 針の破損や紛失の発生頻度が低いことによると思 われるが、個々の症例に打ける具体的な発生状況 や、その対応に言及した報告は少ない。今回我々 は、縫合針を破損し体内で見失ったが幸いにも無 事回収できた 2 症例を経験したので針の破損、紛 失症例に関する文献的考察を行うとともに、今後 我々が留意すべき点について検討した。
症例

症例 138 才、 0 経妊 0 経産

主訴：過多月経、挙児希望

既往歴、家族歴：特記事項なし

現病歴：過多月経と共に、健診で貧血（Hb9.1mg/ dl）を指摘され、近医を受診。子宮筋腫の診断で 当科を紹介受診。同様の診断でGnRHanalogue療 法を 4コース後、腹腔鏡下筋腫摘出術 (Laparoscopic Myomectomy : 以下LM) 目的で入院となった。

内診所見：子宮は全体で新生児頭大。

MRI所見：子宮体部前壁に $9.0 \mathrm{~cm}$ 大筋層内筋腫、 頚部右側に2.0 cm大の漿膜下筋腫を認めた（図 $1)$ 。 
手術所見：予定術式をLMとし、臍部に $12 \mathrm{~mm}$ の 縦切開を入れ、スコープ用トロカールを挿入。両 側上前腸骨棘と臍部線上中央よりやや外側右側に $12 \mathrm{~mm}$ 、左側に $5 \mathrm{~mm}$ の操作様トロカールを挿入 した。子宮前壁の筋腫表面にピトレッシン 4 単位 を局注後、ハーモニックスカルペルにて縦切開を 加え、鈍鋭的に摘出を行ったが、この間、筋腫を 2-0バイクリル針にてfishingを行い铑引系とした (図 2)。前壁の核出後も筋腫に前述の針糸をつけ たまま次の筋腫核出に移った。残りの筋腫核出に はfishingは必要としなかった。全ての筋腫核を摘 出し、子宮筋層を 2 層縫合にて縫合。モルセレー ターによる筋腫の回収前に、先の針糸の回収をし ようとしたところ、針の紛失に気づき、丹念に吸 引管にて血液を吸引しつつ所在を探っていった。 針の吸引管に当たる感覚にて左腸骨窩に針を確認 でき、針先を把持し回収（図 3 ）しょうとしたと ころ、トロカール内で針先以下が破損し脱落。再 び吸引管による探索にて残存針が、膀胱子宮窩腹 膜にあることを確認（図 4)。今度は残存糸を把 持して無事回収でき、閉腹した（図 5 )。

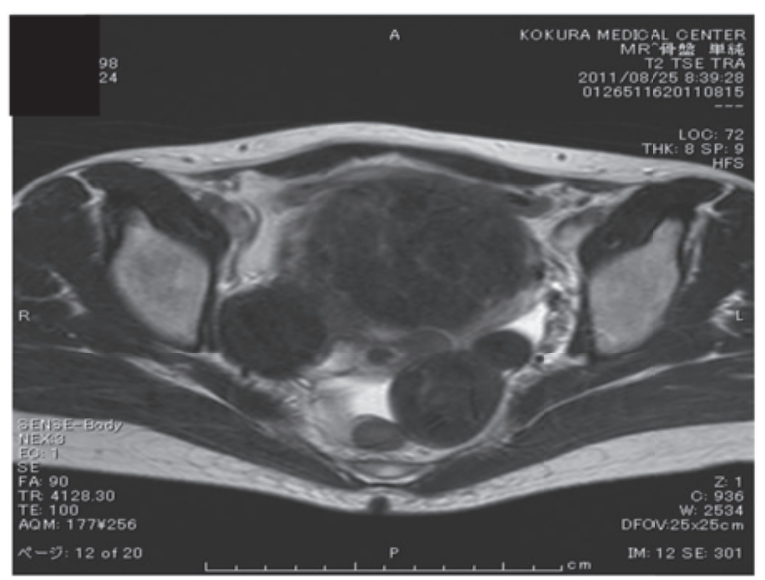

図 1 症例 $1:$ MRI所見

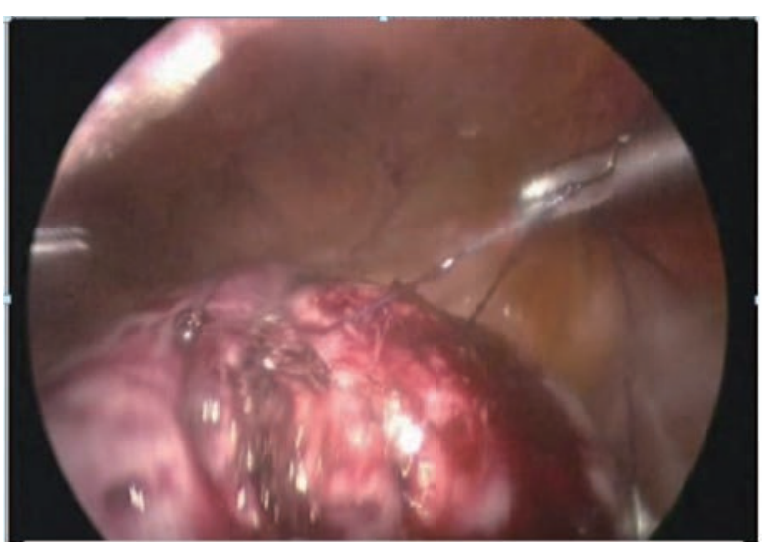

図2 症例 1 : 筋腫のFishing

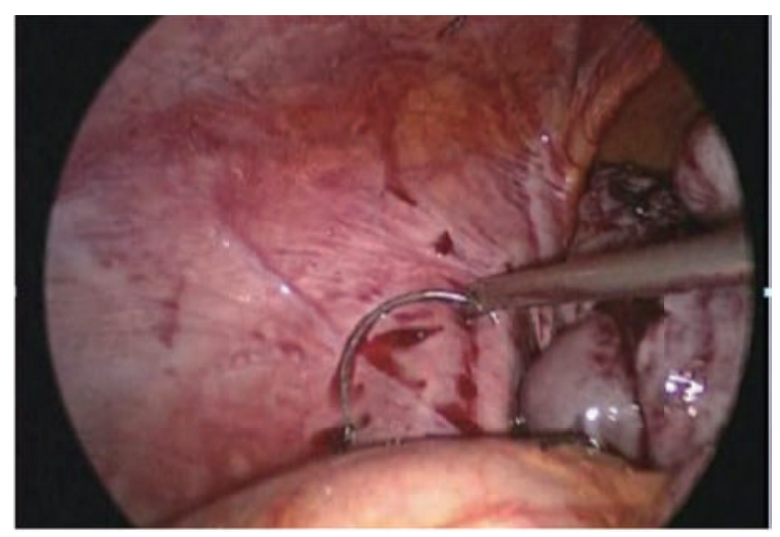

図3 症例 $1 ：$ 針を直接把持しての回収

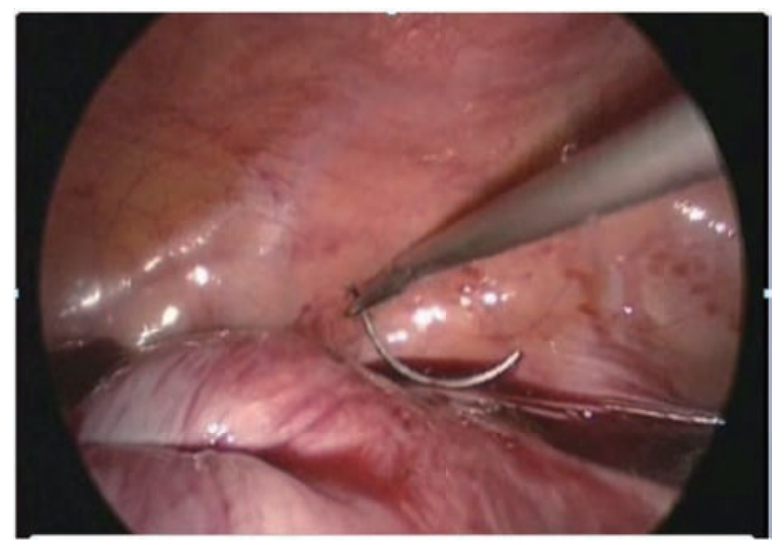

図4 症例 1：2 度目の紛失針の確認と糸を把持しての回収

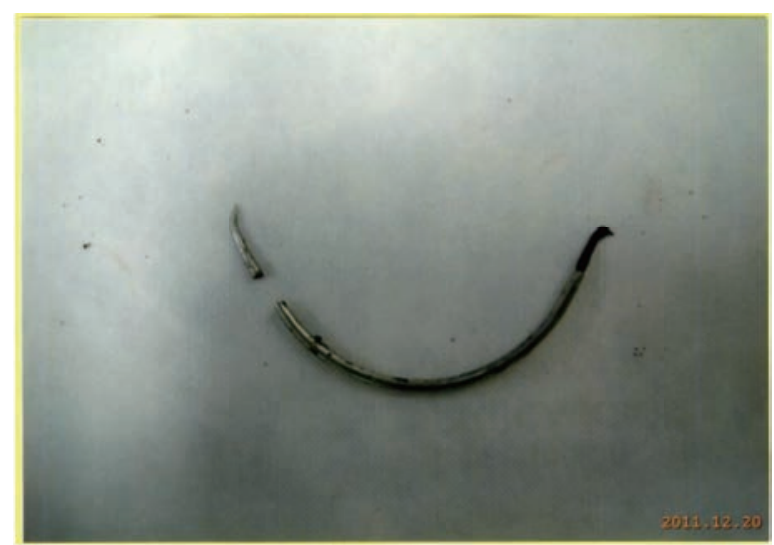

図 5 症例 1 : 回収できた破損針

術後組織診断：Leiomyoma

手術時間：3 時間15分

出血量 : $700 \mathrm{~g}$

症例 249 才、2経妊、2経産

主訴：過多月経

既往歴、家族歴：特記事項なし

現病歴：過多月経にて近医を受診。粘膜下筋腫の 診断で当科を紹介受診。全腹腔鏡下子宮全摘術 (Total Laparoscopic Hysterectomy : 以下TLH) 目的で入院となった。 
内診所見：子宮は全体で熟卵大であり、可動性良 好。

MRI所見：子宮底部漿膜下、右筋層内、子宮内腔 粘膜下に $3.0 \mathrm{~cm}$ 大の筋腫を認めた。

手術所見：予定術式をTLHとし、臍部 $12 \mathrm{~mm}$ の縦 切開にてスコープ用トロカール、両側上前腸棘と 臍部線上中央よりやや外側に $5 \mathrm{~mm}$ の術者操作用 トロカール、臍恥中央に $5 \mathrm{~mm}$ の助手操作用トロ カールを挿入した。膀胱子宮窩腹膜をモノポーラ 一電気メスにて横切開後、左右両側とも子宮円索 足方、および、卵巣固有勒帯後方で、広間膜に切 開を入れ、子宮動脈ならびに、尿管を子宮入口部 まで露出し、両側子宮動脈を絹糸にて結紮後、リ ガシュアーにて切断。子宮動脈断端上方において、 2-0針糸にて子宮傍組織を単結禁縫合した。その 後リガジュアーにて子宮支持勒帯を切断し、下方 へ圧排した後、腟をモノポーラー電気メスにて切 断し、経腟的に子宮を摘出。腟を0バイクリルプ ラスにて右側断端を Z 縫合し、左側断端より連続 縫合にて腟を閉鎖した。この際、連続縫合終了時 に針先先端が鈍になっているのに気づき（図 6 )、 直ちに糸を切断し、先の右側 Z 縫合断端糸と結紮 した。針を体外にて他の針と比較した結果、1.5 $\mathrm{mm}$ 程度先端が紛失していることが判明した。腟 断端部は血液のoozingにて紛失針の確認は困難で あり、新しい吸引瓶を設置し、吸引管による探索 の準備をしていたが、この間に骨盤内を観察して いたところ総腸骨動脈から内腸骨動脈移行部 $2.0 \mathrm{~cm}$ のところに灰色点状物を認め（図 7 ）、これ を回収した。先の針の欠損部と照合し、破損紛失 針であることを確認した（図 8)。この後、 oozing部をバイボーラー電気メスにて凝固止血 し、閉腹した。

術後組織診断：Leiomyoma

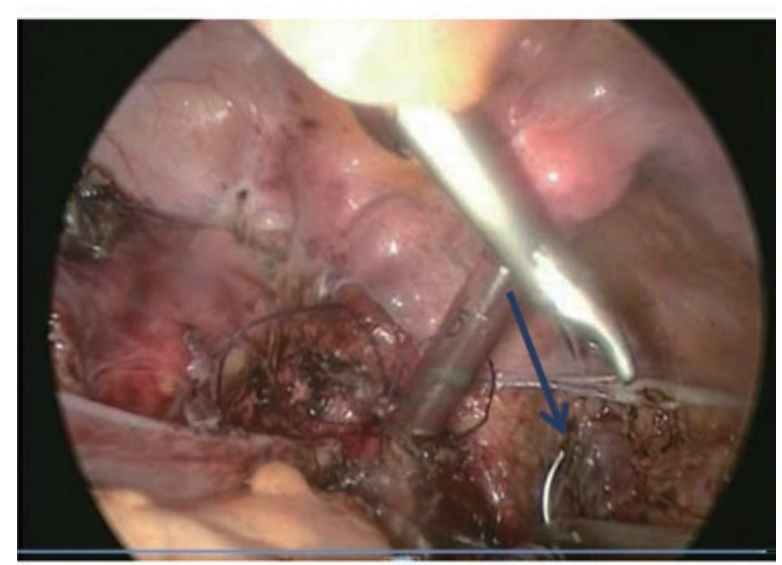

図6 症例 $2 ：$ 針先が鈍になった縫合針

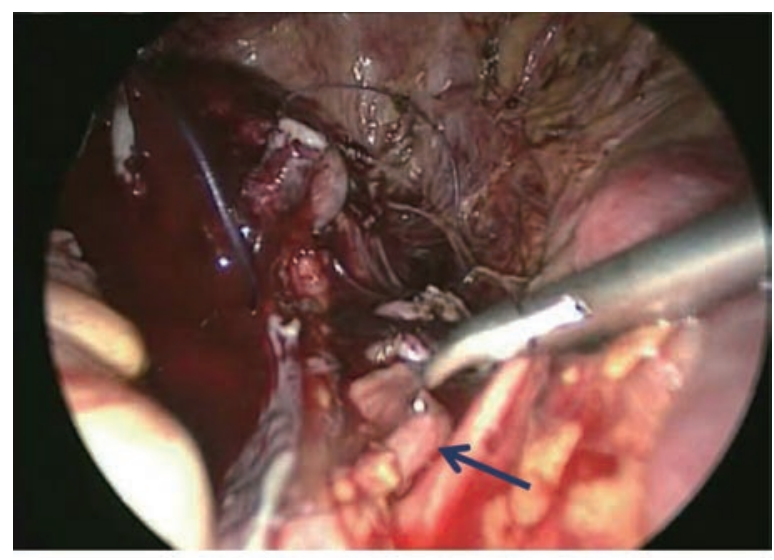

図 7 症例 2 : 右内直腸骨動脈上の紛失針

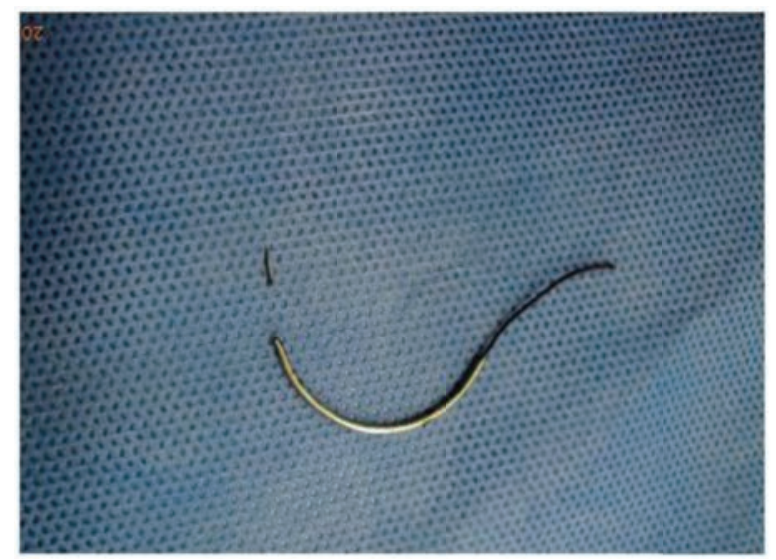

図8症例2：回収できた破損針

手術時間：3 時間 0 分

出血量 : $150 \mathrm{~g}$

\section{考察}

最近の腹腔鏡手術では症例数の増加や適応症例 の拡大が進んでいる。これには患者のニーズだけ ではなく関連機器の多様性や精密性の向上、およ び新しいパワーソースの登場などが寄与している と思われる。これに伴って開腹手術に比べて対処 困難な偶発症に遭遇することがあり、注意が必要 である。今回我々は腹腔鏡手術中、縫合針を破損 し体内で紛失したが、幸いにも無事回収できた症 例を経験した。ビデオ録画をもとに術中の手技を 振り返り、今後注意すべき点を述べるとともに、 文献的考察を行った。

症例 1 では、筋腫のfishingのために使用した針、 糸を筋腫につけたまま放置し、後程回収しようと したため、その後の操作中、何らかの原因で針系 が㐮引され紛失したと推察され、不必要になった 針糸はその時点で回収するべきであった。次に、 紛失針の探索を吸引管にて部位毎に血液を除去し つつ行ったが、腸管背側の見えない部分で針が吸 
引管にあたる感覚にて針の所在を確認することが できた。吸引管の径が紛失針(破損紛失針も含む) より小さい場合は、気づかない間に吸引チューブ や吸引瓶に針が入っていき、その後の探索にかえ って難渋する場合もあると思われるが、今回のよ うに明らかに針が吸引管の径より大きい場合は紛 失針探索法の一つに成り得るのではないかと思わ れた。その後針の所在を確認し、この回収時にト ロカール内で針先以下が脱落し飛散した。これは 針自体を持針器で把持し回収しょうとしたことが 原因であり、さらにこの前段階で、筋腫核の fishingを繰り返している際に針先が既に屈曲して いたことが判明した。針の回収は必ず糸を持って 行う原則を㤐ったこと、および持針器で針先を強 く把持し受針をしたことが原因であると思われ た。腹腔鏡手術に限ることではないが、針先が屈 曲しないための基本操作として、針先をできるか ぎり把持、操作しないという運針の基本を守るこ とが重要であり、持針器での受針は特に初心者で は把持力の加減が難しく注意が必要であると思わ れた。

症例 2 では、腟の連続縫合時、第 1 回目の針刺 入からの受針時に左の持針器で針先を持ち体腔に 平行に引き抜こうとする一方で、右持針器では針 の $1 / 3$ 尾部を持ち針のカーブに沿って引き抜こう とした。この 2 方向の相反する把持牽引方向のた め針が屈曲破損し、針先が飛散したことが推察さ れた。針先 $1.5 \mathrm{~mm}$ 程の紛失であり、症例 1 で用い た吸引管による探索では新しい吸引瓶に取り換え ても針先が吸引されてしまった場合、回収された という同定は容易なことではないと思われ、また たとえ開腹しても $1.5 \mathrm{~mm}$ の針先が簡単に見つかる 可能性は低いことが推察された。しかしながら幸 いにも骨盤内の慎重なスコープでの確認によって 回収が可能であった。破損紛失した針の探索は容 易ではないため、まずこの偶発症を誘発するよう な操作を行わないことが重要である。症例 1 と同 様で、針先が曲がらない基本操作として、今後針 先をできる限り、把持、操作しないこと、および 針先の把持がどうしても必要な場合にはこの様な 偶発症が起こり得ることを意識して把持力を加減 することが必要である。

腹腔鏡手術の合併症を術中に起こったものと術 後に起こったものに分けると、日本産科婦人科内 視鏡学会のアンケート調查 ${ }^{3)}$ では、術中の偶発症 もしくは合併症の頻度は2006年に $0.61 \% 、 2007$ 年 に $0.62 \%$ 、術後では 2006 年に $0.41 \% 、 2007$ 年に 0.74
\%の症例に発生していた。この調査の中で、今回 の針の破損、紛失は具体的頻度が記載されている 項目のなかで「その他」の0.19\%に含まれ、本偶 発症の頻度は少ないことが伺える。

森本ら ${ }^{1)}$ は、自院の全科を対象とした腹腔鏡手 術の有無を問わない2009年の全手術4034例の術中 手術器具破損が 3 例 $(0.07 \%)$ であったと報告し ている。また、佐藤ら ${ }^{2)}$ は2141例の腹腔鏡手術中 2 例 $(0.09 \%)$ の針紛失を報告している。頻度は 少ないものの今回の症例のような針の破損、紛失 はその後の対処にかなりの労力を要するものであ る。特に腹腔鏡手術の場合は、その探索は限定さ れた視野空間から開腹術に比べかなり困難であ る。

針紛失に対する探索には、MRI撮影の困難性、 レ線やCTによる放射線撮影、再手術の可能性な どが問題となり、また、針の遺残は、その後の慢 性疼痛、腸管穿孔、瘦孔形成、血管の損傷を引き 起こしうる ${ }^{4,5)}$ 。また、器具の紛失遺残は、患者や 医療スタッフにとって大変な精神的負担を伴うと ともに、多額の損害賠償も生じ、アメリカでは 2.6億ドルまでに至っているとの報告もある6)。

縫合針の破損に関して具体的に論じた文献は検 索しえなかったが、この予防策としてはやはり針 先を強く把持した操作を厳に慎むことであろう。

針の紛失に関して、Ponrartana $ら^{7)}$ は、 $10 \mathrm{~mm}$ 以下の針のX線による探索は困難であると述べて おり、また、Macilquhamら ${ }^{8)}$ も線上確認でき るのは $13 \mathrm{~mm}$ の針であり、その確率も13\%である としている。佐藤ら ${ }^{2)} も$ 針紛失例にX線を用い腹 腔内を探索したが回収できず開腹術へ移行したと 述べている。このように紛失針の回収は容易では なく、まず第一に予防策を講じることが大切であ る。針紛失には色々な原因がありうるが、針の回 収時には、トロカールの腹腔内先端を上方へ傾け、 針の落下を防ぐといった方法" ${ }^{9)}$ 紛失予防の一つ となりうるであろう。

針紛失に遭遇後の対処として、腹腟内を生理食 塩水で満たし、骨盤低位にすると、針がダグラス 窩に移動して発見できることもあるとの報告 ${ }^{2)} も$ ある。また、Bartoら ${ }^{10)}$ は腹腔鏡用磁石 (Laparoscopic magnet）の有用性を動物実験にて確認している。 彼らは決められた位置に置かれた針をこの Laparoscopic magnetを利用して1 ケ所30秒以内 で確実に回収し、また、盲目的に置かれた15本の 針に対して決められた方向性を持ってスクロール することによって 3 分以内に安全な回収をするこ 
とができたと述べており、今後の本邦における実 用化が望まれる。

\section{結語}

腹腔鏡下手術において、縫合針が破損、紛失し た 2 症例を経験した。今回の経験から (1)縫合針は 屈曲に気づいた時点で回収する(2)針糸は不必要に なった時点でなるべく早く回収する(3)針の回収は 必ず糸を把持して回収する(4)針の屈曲、破損を防 ぐ基本操作として受針時にはできるだけ針先を把 持、操作しない。以上のことを認識して今後の手 術に臨むこととした。本論文の要旨は第 8 回九州 産婦人科内視鏡手術研究会において発表した。

\section{文献}

1）森本泰介、鈴木真美、平田敦宏：インシデントレポ 一ト分析から導入した手術関連臨床指標、日本医療 マネジメント学会雑誌、2011；11：231-235.

2 ）佐藤雄一、武内裕之、木下勝之：婦人科救急医療の A B Cシリーズ 腹腔鏡下手術中のアクシデント： 多量出血,副損傷 産科と婦人科、2002；85：13571365.

3）産婦人科領域の内視鏡手術に関するアンケート調查 -2006 年度と 2007 年度の集計結果報告 - 日産婦内 視鏡学会誌 $2009 ; 24: 515-520$.

4) Greenberg CC, Gawande AA. Beyond Counting:current evidence on the problem of retaining foreign bodies in surgery. Ann Surg.2008;247:19-20.

5 ) Stawicki SP, Lombardo G, Chovanes J. Retained surgical foreign bodies: a synopsis.OPUS12 Scientist.2008;2:1-5.

6) Natalie W, Verdicts \& settlements July 31 2006: needle left in patients body yields $\$ 2.6$ million verdict. Lawyers USA. 2006;167:1-3.

7) Ponrartana S, Coakley V, Yeh B.Accuracy of plain abdominal radiographs in the detection of retained surgical needles in the peritoneal cavity. Ann Surg.2008;247:8-12.

8 ) Macilquham M, Riley RG, Grossberg P.:Identitying lost surgical needles:using radiographic techniques. AORNJ,Denver.2003;78:73-79.

9 ）内田一徳：内視鏡下縺合・結禁のコッと工夫 2006; 160-163 永井書店

10) Barto W, FRACS M, Yazbek C, et al:: Finding a lost needle in laparoscopic surgery. Surg Laparosc Endosc Percutan Tech.2011;21:163-165. 